\title{
Non-indigenous macroinvertebrate species in Lithuanian fresh waters, Part 1: Distributions, dispersal and future
}

\author{
K. Arbačiauskas ${ }^{(1)}$, G. Višinskienè ${ }^{(1)}$, S. Smilgevičiené(1), V. Rakauskas ${ }^{(1)}$ \\ Received December 19, 2010 \\ Revised August 23, 2011
}

Accepted September 20, 2011

\section{Abstract}

Key-words: non-indigenous, benthos, invasion, inland waters, feeding habit
Biological invasions are of increasing global concern. They impact on biodiversity and may result in high economic loss. This demands improvement in knowledge of the dynamics of species dispersal with the goal of preventing future invasions, and predicting and reducing undesirable impacts. This study reports on non-indigenous macroinvertebrate species (NIMS) which have invaded Lithuanian fresh waters. Fifteen NIMS have been recorded during a 12-year study. They include one cnidarian, two molluscan and twelve crustacean species. The deliberate introduction of peracaridans and crayfish for fishery and aquaculture enhancement has substantially contributed to the current NIMS composition. Invaders of Ponto-Caspian origin are dominant, and the collector-gatherers are the largest group with respect to feeding mode. Current NIMS distributions, the history of their primary invasion and patterns of local dispersal are analysed. The main invasion vectors have been inland shipping and deliberate introductions, while secondary spread proceeded both naturally and by various human mediated vectors. The current distribution of most NIMS may remain constant in the future, whilst further expansion of a few NIMS, which possess good dispersal abilities and are well-adapted to freshwater environments, seems very probable. Using multivariate analysis of data from water bodies with established peracaridan invaders, allowed predictions on which unsurveyed water bodies could contain such invaders. Invasions of new NIMS and diversification of donor areas, pathways and vectors are considered.

\section{RÉSUMÉ}

Les espèces de macroinvertébrés non-indigènes dans les eaux douces lituaniennes, Partie 1 : distribution, dispersion et devenir

\footnotetext{
Mots-clés: Les invasions biologiques constituent une préoccupation mondiale croissante. non-autochtones, Elles ont une incidence sur la biodiversité et peuvent entraîner des pertes éconobenthos, invasion, miques élevées. Cela exige l'amélioration des connaissances sur la dynamique de la dispersion des espèces dans le but de prévenir les invasions futures, et de prédire eaux intérieures, habitudes alimentaires et réduire les effets indésirables. Cette étude liste les espèces de macroinvertébrés non-indigènes (NIMS) qui ont envahi les eaux douces lituaniennes. Quinze NIMS ont été enregistrées au cours d'une étude de 12 ans. Elles comprennent un cnidaire,
} 
deux mollusques et douze espèces de crustacés. L'introduction délibérée de péracarides et d'écrevisses pour le développement de la pêche et de l'aquaculture a considérablement contribué à la composition actuelle des NIMS. Les envahisseurs d'origine pontocaspienne sont dominants, et les cueilleurs-collecteurs constituent le groupe le plus représenté, eu égard au mode d'alimentation. Les distributions actuelles des NIMS, I'histoire de leur invasion initiale et des modèles de dispersion locale sont analysés. Les vecteurs principaux d'invasion ont été la navigation intérieure et les introductions délibérées, alors que les propagations secondaires se sont déroulées tant naturellement que par divers vecteurs humains. La répartition actuelle de la plupart des NIMS peut rester stable dans le futur, tandis que l'expansion de quelques NIMS, qui possèdent de bonnes capacités de dispersion et sont bien adaptées à des environnements d'eau douce, semble très probable. En utilisant une analyse multivariée des données de plans d'eau avec des envahisseurs péracarides établis, des prédictions sont faites sur les plans d'eau non suivis qui pourraient contenir de tels envahisseurs. Des invasions de NIMS nouvelles et la diversification des zones donneuses, des voies et des vecteurs de propagation sont considérées.

\section{INTRODUCTION}

Biological invasions are among the main threats to biodiversity and the second leading driver of animal extinctions (Millennium Ecosystem Assessment, 2005). The spread of species outside their natural range in inland waters seem to have higher rates of indigenous species endangerment and extinction than that of marine or terrestrial environments (Ricciardi and Rasmussen, 1998; Dudgeon et al., 2006). Invasions of non-indigenous species that impact on biodiversity may ultimately cause significant environmental damage leading to changes in community structure and function, and the alteration of ecosystem-level services, resulting in high economic loss, which has been well-documented in European fresh waters (see Genovese, 2007). This demands improvement in our knowledge of the dynamics of species spread with the goal of preventing or controlling future invasions and the ability to predict and reduce undesirable impacts (Shea and Chesson, 2002). The first steps are to identify the nonindigenous species which have invaded a region, and to establish the vectors and pathways of their dispersal. Inventories of particular species, i.e. the reconstruction of the history of their spread, are of significance for describing patterns of non-indigenous species dispersal and for making predictions at both regional and global scales (e.g. Lonsdale, 1999; Rabitsch and Essl, 2006; Karatayev et al., 2008).

The purpose of this paper is to present the first comprehensive overview of non-indigenous macroinvertebrate species (NIMS) occurring in Lithuanian fresh waters. Using data from a 12-year study and historical information, we aimed to reveal the current NIMS distribution and to analyse the history of specific NIMS invasion and spread, characterizing the types of NIMS which have invaded and thereby ultimately predicting future invasions. It is noteworthy that some NIMS from Lithuanian inland waters have started to invade the Baltic Sea basin and beyond (Jazdzewski and Konopacka, 2000; Jazdzewski et al., 2004; Arbačiauskas and Gumuliauskaitè, 2007; Audzijonyte et al., 2008).

\section{MATERIAL AND METHODS}

\section{> STUDY AREA}

Lithuania is within the Baltic Sea drainage basin area. Its territory occupies a little over $64800 \mathrm{~km}^{2}$ of which $72 \%$ is in the basin of the largest river, the Nemunas River. Basins of the other large rivers which include the Venta River basin, the Lielupe River basin (the Mūša and Nemunèlis rivers) and the Dauguva River basin (the Dysna River) and a few other rivers 
(including the Šventoji and Danè) that empty directly into the Baltic Sea or the Curonian Lagoon, comprise 8, 14, 3 and $3 \%$ of the area, respectively (Figure 1A). There are 2850 lakes with a surface area over 0.5 ha among which 942 and 160 lakes are larger than 10 and 100 ha, respectively (Gailiušis et al., 2001).

The Nemunas River, was impounded in 1959 and a reservoir for a hydroelectric power plant, the Kaunas Water Reservoir (WR), was created. The Kaunas WR has a surface area of $63.5 \mathrm{~km}^{2}$ and mean depth of $7.3 \mathrm{~m}$. This reservoir is important for the dispersal history of NIMS in Lithuanian waters and beyond, being the first place in the Baltic Sea basin where an array of Ponto-Caspian peracaridan species were deliberately introduced (Gasiūnas, 1972).

The Nemunas River which originates in the territory of Belarus, has been connected by canals with the Pripyat River (the Dnieper River basin) and the Vistula River. The first canal, the Oginsky Canal, was constructed during 1765-1784. From the end of the 19th century it was used only for local shipping, and it has been inoperable since the 1940s. In1980 it was infilled, however, the Belarusian government plans to reconstruct it and to re-establish commercial shipping. The second canal, the Augustow Canal, was built between 1824 and 1839, destroyed during the war of 1941-1945 but has recently been entirely reconstructed (Karatayev et al., 2008). The Oginsky Canal provided a direct hydrological connection and migration route for aquatic organisms between the basins of the Baltic and Black seas at least until the middle of the 20th century, and the Augustow Canal currently links the two Baltic Sea river basins. Consequently, the Nemunas River represents the northern branch of a central European invasion corridor which connects the Dnieper $\rightarrow$ Vistula $\rightarrow$ Oder $\rightarrow$ Elbe $\rightarrow$ Rhine rivers (Bij de Vaate et al., 2002). In Lithuania itself, two canals connecting different river basins may be important for a local NIMS dispersal. The construction of the Venta-Dubysa Canal was started in 1825 and although the canal construction remains unfinished, it provides a hydrological connection between the basins of the Nemunas and Venta rivers. The Sanžile Canal was built in 1930 and is used for interbasin water diversion. It connects the basins of the Nemunas and Lielupe rivers (Figure 2A) (Gailiušis et al., 2001).

\section{> DATA AND ANALYSIS}

Distribution data were obtained in Lithuanian inland waters by different sampling methods during a 12-year study from 1998 to 2010 . The main methods employed were sampling by a standard dip net, catches by a sledge net or dredge, and visual inspection of bottom substrates. Extensive information on NIMS was obtained through surveys of lakes (1998-2000) and large and middle-sized rivers (68 sites in 14 rivers, 2007-2008). This was supplemented with occasional investigations of various other water bodies over the study period. Data on non-indigenous crayfish species presented in this paper also includes information from the "grey" literature (e.g. scientific reports for Fish Stock Department and personal interviews).

To characterise the array of NIMS occurring in Lithuanian fresh waters, taxonomic composition by phylum (subphylum) and composition by feeding habit were analysed. The same feeding habit categories in Karatayev et al. (2009) following Mandaville (2002) were used (i.e. collector-gatherer, predator and collector-filterer, the latter including suspension feeders). Deliberate introductions of Ponto-Caspian mysids and amphipods were undertaken in more than 100 Lithuanian lakes. To predict which unsurveyed water bodies may contain PontoCaspian peracaridans, a stepwise discriminant analysis was applied on the log-transformed morphometric characteristics of those lakes for which information on the success or failure of translocated species to become established was already available. Predictions were derived based on the classification functions obtained and on a priori proportional to group size classification probabilities, with all analysis performed using Statistica 6.1 software. 


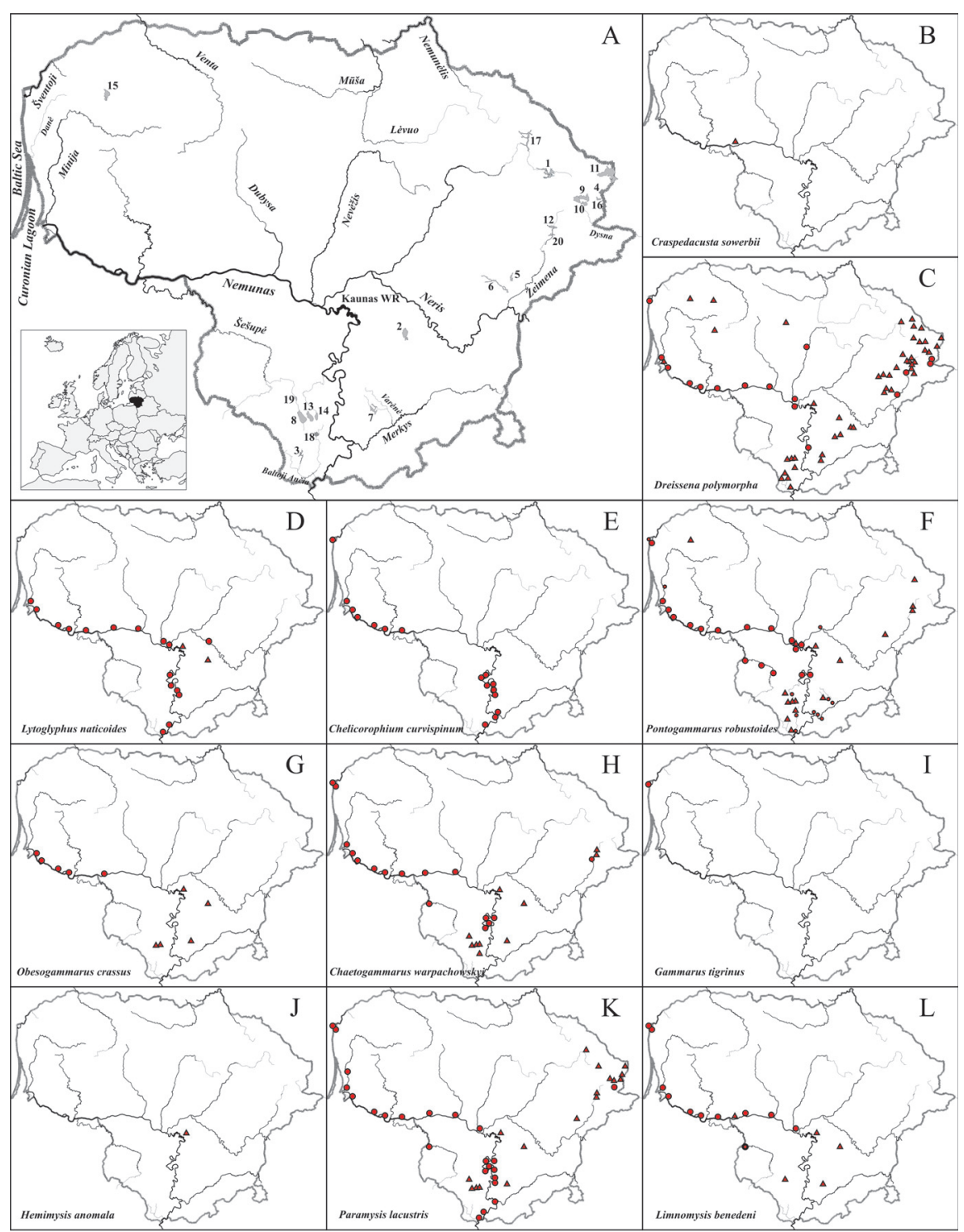

\section{Figure 1}

Rivers and other water bodies relevant to the study (A) and distributions of non-indigenous macroinvertebrate species: freshwater jellyfish Craspedacusta sowerbii (B); mussel Dreissena polymorpha (C); snail Lytoglyphus naticoides (D); amphipods Chelicorophium curvispinum (E), Pontogammarus robustoides (F), Obesogammarus crassus (G), Chaetogammarus warpachowskyi $(H)$ and Gammarus tigrinus (I); mysids Hemimysis anomala (J), Paramysis lacustris $(K)$ and Limnomysis benedeni $(L)$. Numbers correspond to the water body names in Table I (A). Circles and triangles indicate localities in flowing and stagnant waters (lakes, water reservoirs, quarries) (B-L), respectively. Large and small circles for P. robustoides (F) indicate localities of abundant and sparse occurrence, respectively.

Figure 1

Rivières et plans d'eau concernés par l'étude $(A)$ et distributions des espèces de macroinvertébrés nonindigènes : la méduse d'eau douce Craspedacusta sowerbii (B) ; la moule Dreissena polymorpha (C) ; l'escargot Lytoglyphus naticoides (D) ; les amphipodes Chelicorophium curvispinum (E), Pontogammarus robustoides $(\mathrm{F})$, Obesogammarus crassus $(\mathrm{G})$, Chaetogammarus warpachowskyi $(\mathrm{H})$ et Gammarus tigrinus (I) ; les mysidacés Hemimysis anomala (J), Paramysis lacustris (K) et Limnomysis benedeni (L). Les numéros correspondent aux noms de masse d'eau dans le tableau I (A). Les cercles et les triangles indiquent les localités dans les eaux courantes et stagnantes (lacs, réservoirs, carrières) (B-L), respectivement. Grands et petits cercles pour $P$. robustoides $(F)$ indiquent les localités d'apparition abondante et clairsemée, respectivement. 


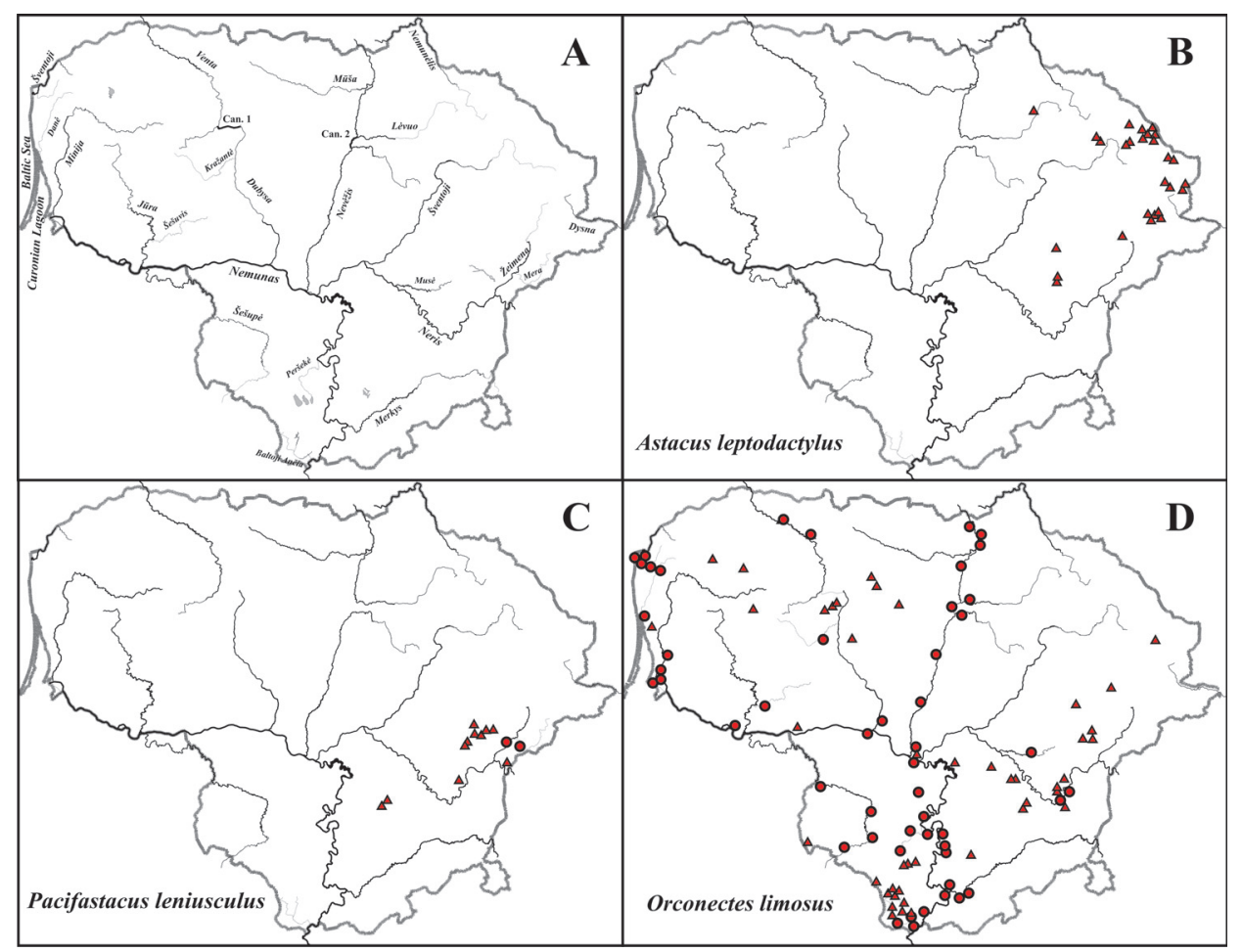

\section{Figure 2}

Location of rivers relevant to the study and large lakes recently invaded by the spiny-cheek crayfish $(A)$ and distributions of non-indigenous crayfish Astacus leptodactylus $(B)$, Pacifastacus leniusculus (C) and Orconectes limosus (D). Can. 1 and Can. 2 indicate the Venta-Dubysa and Sanžile canals (A), and circles and triangles show localities in flowing and stagnant waters (lakes, water reservoirs, quarries) (B-D), respectively. NB Some historical localities indicated for $\mathrm{A}$. leptodactylus and $\mathrm{P}$. leniusculus may currently be extinct.

\section{Figure 2}

Situation des rivières et des grands lacs concernés par l'étude récemment envahis par l'écrevisse américaine $(A)$ et distributions d'espèces non-indigènes d'écrevisse Astacus leptodactylus (B), Pacifastacus leniusculus (C) et Orconectes limosus (D). Can. 1 et Can. 2 indiquent les canaux VentaDubysa et Sanžilè (A), et les cercles et triangles indiquent les localités dans les eaux courantes et stagnantes (lacs, réservoirs, carrières) (BD), respectivement. NB Certaines localités historiques indiquées pour $A$. leptodactylus et $P$. leniusculus peuvent actuellement être éteintes.

\section{DISTRIBUTIONS}

During the study period, fifteen NIMS were recorded in Lithuanian inland waters (NIMS in the Curonian Lagoon were not considered in this paper, see Zettler and Daunys, 2007): freshwater jellyfish Craspedacusta sowerbii Lankester, 1880, mussel Dreissena polymorpha Pallas, 1771, snail Lithoglyphus naticoides Pfeiffer, 1828, amphipods Chelicorophium curvispinum Sars, 1895, Pontogammarus robustoides Sars, 1894, Obesogammarus crassus Sars, 1894, Chaetogammarus warpachowskyi Sars, 1894 and Gammarus tigrinus Sexton, 1939, mysids Paramysis lacustris Czerniavsky, 1882, Limnomysis benedeni Czerniavsky, 1882 and Hemimysis anomala Sars, 1907, shrimp Palaemon elegans Rathke, 1837, and crayfish Astacus leptodactylus Eschscholtz, 1823, Pacifastacus leniusculus Dana, 1852 and Orconectes limosus Rafinesque, 1817. 


\section{$>$ CNIDARIA}

The presence of freshwater jellyfish C. sowerbii was recorded only once, in 2002. During August, a population explosion of $C$. sowerbii medusae was observed in an old water-filled gravel pit located near the Nemunas River (Figure 1B). This quarry has no direct connection with other water bodies, even during the Nemunas River springtime floods.

\section{$>$ MOLLUSCA}

The Ponto-Caspian mussel $D$. polymorpha is widely distributed over Lithuanian stagnant waters and was recorded in 47 lakes and water reservoirs throughout the country (Figure 1C). In flowing waters it was only found downstream of source populations in stagnant waters, and a few sites where flow velocity was low. It was present in dip net samples collected from the lower section of the Nemunas River (downstream of the Kaunas WR), at a single site above the Kaunas WR, at two sites on the Nevėžis River, the lowest stretch of the Minija River, the mouth of the Šventoji River and the Žeimena and Dysna rivers (downstream from lakes Žeimenys and Dysnykštis, respectively) (Figures 1A, 1C). The snail L. naticoides occurred at 11 sites on the Nemunas River and 5 sites in the lower sections of its large tributaries: the Minija, Nevèžis, Neris and Baltoji Ančia rivers. It was only observed upstream of the river mouth in the Neris River, the second largest Lithuanian river. In addition to the Kaunas WR site, an abundant population of this snail was also found at Elektrènai WR (Figure 1D).

\section{$>$ AMPHIPODA}

The amphipod C. curvispinum, the first crustacean invader, mainly inhabits the Nemunas River. It was absent only in the river stretch below Kaunas WR where pontogammarid $P$. robustoides abundance was exceptionally high. C. curvispinum was also detected in the lowest stretch of the Minija River and the mouth of the Šventoji River (Figure 1E).

Other Ponto-Caspian amphipods, P. robustoides, O. crassus and C. warpachowskyi, were deliberately introduced into the Kaunas WR, where they have survived until today. Currently the most widely distributed among amphipods is $P$. robustoides. It occurs with high abundance in the Nemunas River below the Kaunas WR and above it to the river-reservoir transition zone. Large numbers of this pontogammarid were recorded in the Šešupè River and the lowest stretches of the Minija, Nevéžis, Neris and Šventoji rivers. It was present in the lower sections of the Merkys and Baltoji Ančia rivers including the dammed-up stretch of the latter. Several well-establish populations of this amphipod were also detected in small rivers or streams downstream of the lakes. $P$. robustoides was recorded in stagnant waters of the Elektrènai and Antalieptè WRs and 11 lakes and was observed in the quarry close to the Nemunas River (Figures 1A, 1F, Table I).

The pontogammarid $O$. crassus was only recorded in the lowest stretch of the Nemunas River, Elektrènai WR and 3 lakes (Figure 1G, Table I). The Ponto-Caspian gammarid C. warpachowskyi had a wider distribution and was found in the lower section of the Nemunas River and above the Kaunas WR. It was present at the Nemunas River sites (12 and $20 \mathrm{~km}$ upstream), where P. robustoides was absent. C. warpachowskyi was also recorded at the lowest stretches of the Minija and Šventoji rivers, the Šešupe River and at the outflow of the Žeimena River from the lake with established population of the species. The species was detected in stagnant waters of the Elektrenai WR and 8 lakes (Figure $1 \mathrm{H}$, Table I). The latest amphipod invader of Lithuanian inland waters G. tigrinus during this survey was only observed in the mouth of the Šventoji River (Figure 1I).

\section{$>$ MYSIDA}

Ponto-Caspian mysids in common with amphipods were deliberately translocated to Kaunas WR. Among them, $H$. anomala is currently only found there (Figure $1 \mathrm{~J}$ ), whilst $P$. lacustris has a wide distribution across inland waters. Together with $L$. benedeni, $P$. lacustris inhabits the 


\section{Table I}

Lakes and water reservoirs (WR) inhabited by Ponto-Caspian peracaridan species. Morphometry: area (A); maximum depth $\left(\mathrm{H}_{\text {max }}\right)$; average depth $\left(\mathrm{H}_{\mathrm{ave}}\right)$. Ponto-Caspian species: Paramysis lacustris (PL); Limnomysis benedeni (LB); Pontogammarus robustoides (PR); Obesogammarus crassus (OC); Chaetogammarus warpachowskyi (CW). Asterisks denote lakes not subject to deliberate introductions.

\section{Tableau I}

Les lacs et réservoirs (WR) colonisés par les espèces péracaridiennes Ponto-Caspiennes. Morphométrie : surface $(A)$; profondeur maximale $\left(H_{\max }\right)$; profondeur moyenne $\left(H_{\text {ave }}\right)$. Espèces Pontocaspiennes : Paramysis lacustris (PL) ; Limnomysis benedeni (LB) ; Pontogammarus robustoides (PR) ; Obesogammarus crassus (OC) ; Chaetogammarus warpachowskyi (CW). Les astérisques indiquent les lacs non soumis à des introductions délibérées.

\begin{tabular}{|c|c|c|c|c|c|c|}
\hline No. & Water body & $A$ (ha) & $H_{\max }(\mathrm{m})$ & $H_{\text {ave }}(\mathrm{m})$ & Mysids & Amphipods \\
\hline 1 & Antalieptè WR & 1572 & 46 & 7.2 & PL & PR \\
\hline 2 & Elektrènai WR & 1290 & 30 & 7.1 & PL, LB & PR, OC, CW \\
\hline 3 & Ančia* & 491 & 26 & 9.3 & & PR \\
\hline 4 & Apvardai $^{*}$ & 425 & 5 & 2.6 & PL & \\
\hline 5 & Arinas & 392 & 18 & 6.8 & PL & \\
\hline 6 & Asveja & 982 & 50 & 14.9 & & PR \\
\hline 7 & Daugai & 911 & 44 & 13.2 & PL, LB & PR, OC, CW \\
\hline 8 & Dusia & 2334 & 33 & 15.4 & PL & PR, OC, CW \\
\hline 9 & Dysnai & 2401 & 6 & 3.0 & PL & \\
\hline 10 & Dysnykštis & 558 & 5 & 2.7 & PL & \\
\hline 11 & Drūkšiai $^{*}$ & 4480 & 33 & 8.2 & PL & \\
\hline 12 & Lūšiai ${ }^{*}$ & 391 & 37 & 13.9 & PL & PR, CW \\
\hline 13 & Metelys & 1290 & 15 & 6.8 & PL & PR, OC, CW \\
\hline 14 & Obelija & 573 & 8 & 4.5 & PL & PR, CW \\
\hline 15 & Plateliai & 1182 & 46 & 11.4 & & PR \\
\hline 16 & Rūžas & 219 & 4 & 2.5 & PL & \\
\hline 17 & Sartai & 1337 & 21 & 5.7 & PL & \\
\hline 18 & Seirijis $^{*}$ & 501 & 19 & 8.0 & & PR, CW \\
\hline 19 & Simnas & 243 & 4 & 2.3 & PL, LB & PR, CW \\
\hline 20 & Žeimenys & 436 & 24 & 6.9 & PL & CW, PR \\
\hline
\end{tabular}

lower section of the Nemunas River, the lowest stretches of the Minija, Nevéžis and Šventoji rivers, and was observed in the Šešupe River. At these sites $L$. benedeni was the more abundant and was also observed in the quarry close to the Nemunas River. In flowing waters, a single mysid species $P$. lacustris was recorded in the Nemunas River upstream of the Kaunas WR, the more upstream site of the Minija River, and the Dysna River. It also inhabits two water reservoirs and 16 lakes, while $L$. benedeni was only recorded at the Elektrenai WR and two lakes (Figures 1K, 1L; Table I). 


\section{$>$ DECAPODA}

The earliest crayfish immigrant of Lithuanian waters was the narrow-clawed crayfish A. leptodactylus. Highly abundant populations were currently found in the Kupiškis WR on the Lèvuo River and Lake llgis. It is estimated that $A$. leptodactylus may be present in around 25-30 lakes (including reported but currently unconfirmed locations) most of which are located in the north-eastern part of the country (Figure 2B). Data on the current distribution of the signal crayfish $P$. leniusculus is rather scarce. Available information suggests that this nonindigenous crayfish inhabits 4 lakes, may be present in another 7, and has recently established in the flowing waters of the Žeimena and Mera rivers (Figure $2 \mathrm{C}$ ).

Meanwhile, the distribution of the spiny-cheek crayfish $O$. limosus is much wider than that of other non-indigenous crayfish species. In the flowing waters of the Nemunas River basin, O. limosus was recorded in the lower and middle sections of the Nemunas River and the lowest stretches of the Minija, Dubysa and Merkys rivers. It was present in the Šešupè, Nevėžis, Neris, Baltoji Ančia, Peršekè, Musè, Kražantè and Šešuvis rivers (Rakauskas et al., 2010) (Figures 2A, 2D). The species was also detected in the other river basins within Lithuania. O. limosus was found in the Šventoji River and its tributary, and the Danè, Venta, Mūša and Lèvuo rivers. In stagnant waters, the spiny-cheek crayfish occurred at 44 locations including lakes of various size, water reservoirs and quarries (Figure 2D). It is present in the Curonian Lagoon and was even observed in the coastal Baltic waters.

The marine shrimp $P$. elegans was found at the mouth of the Šventoji River, where it empties directly into the Baltic Sea (Figure 1I), at the same location that amphipod G. tigrinus was recorded.

\section{HISTORY OF INVASION AND LOCAL DISPERSAL}

Historically, the biological invasion of Lithuanian inland waters can be divided into three phases. The first invasion wave took place between the end of the 18th century and the end of the 19th century, when the basins of the Nemunas and Dnieper rivers were connected by the Oginsky Canal. The second wave was associated with the deliberate introduction of crustaceans during the 1960s and 1970s. The third wave comprised the modern invasions which have occurred since the 1990s. An analysis of NIMS local dispersal has been made with respect to these invasion waves. General information on the history of NIMS invasion and local dispersal is given in Table II.

\section{> FIRST INVASION WAVE}

The first newcomers, the Ponto-Caspian mussel D. polymorpha and snail L. naticoides, probably established in Lithuanian inland waters at the end of the 18th century. Inland shipping between the Nemunas and Dnieper river basins was the main vector of primary invasion. The amphipod C. curvispinum similarly invaded and established at this time or shortly after. The Ponto-Caspian molluscs and the amphipod were recorded for the first time in fresh waters during the 1930 s and 1920s, respectively (Table II). Currently, D. polymorpha has the widest distribution being found in fresh, primarily stagnant and lentic waters. During the initial phase of local dispersal, its spread throughout lakes was related to human-mediated accidental introductions, probably due to commercial fishing and translocation of boats between water bodies. This pattern of spread was similarly suggested for Belarusian waters (Karatayev et al., 2003). In the second half of the 20th century, the distribution of $D$. polymorpha (zebra mussel) in inland waters was enhanced by deliberate translocation to lakes which were devoid of the species. These introductions were explained by a need to improve feeding conditions for commercially important fish species, primarily roach, which readily consumes these mussels. Records show that between 1959 and 1985, zebra mussels were released into more than 30 lakes (Arbačiauskas et al., 2010). The current distribution of D. polymorpha would also be influenced by its natural downstream spread from source 


\section{Table II}

Non-indigenous macroinvertebrate species recorded in Lithuanian inland waters with information on their appearance, origin and dispersal vectors. Appearance: year of first introduction (recorded establishment) or approximate period of invasion (first record). Origin: eastern Asian (EA), North American (NA), Ponto-Caspian (PC), southeastern European (SE), western European (WE). Vectors of primary introduction and expansion within the country arranged in accordance with their importance: deliberate introduction $(D)$, unofficial introduction $(U)$, accidental introduction (A), inland shipping (IS), marine shipping (MS), natural dispersal (N). References: Arbačiauskas and Lesutienè, 2005 (1); Cukerzis, 1970 (2), 1979 (3); Gasiūnas, 1963 (4), 1968 (5); Jazdzewski, 1980 (6); Koreiva, 1994 (7); Lepehne, 1924 (8); Mikha, 1901 (9); Schlesch, 1937 (10); Schlesch and Krausp, 1938 (11); Šivickis, 1934 (12); current study (13). NB G. tigrinus and P. elegans were recorded in the Curonian Lagoon in 2004 (Daunys and Zettler, 2006; Zettler and Daunys, 2007).

\section{Tableau II}

Espèces non-indigènes de macroinvertébrés rencontrées dans les eaux intérieures lituaniennes avec des informations sur leur origine géographique, leur vecteur d'introduction et leur dispersion. Introduction : année de la première introduction (établissement enregistré) ou période approximative de l'invasion (premier enregistrement). Origine : Est asiatique (EA), Amérique du Nord (NA), Ponto-Caspienne (PC), le sudest européen (SE), I'Europe occidentale (WE). Vecteurs d'introduction et expansion dans le pays disposés en fonction de leur importance : introduction délibérée (D), introduction officieuse (U), introduction accidentelle (A), navigation intérieure (IS), transport maritime (MS), dispersion naturelle (N). Références : Arbačiauskas et Lesutiené, 2005 (1) ; Cukerzis, 1970 (2), 1979 (3) ; Gasiūnas, 1963 (4), 1968 (5) ; Jazdzewski, 1980 (6) ; Koreiva, 1994 (7) ; Lepehne, 1924 (8) ; Mikha, 1901 (9) ; Schlesch, 1937 (10) ; Schlesch et Krausp, 1938 (11) ; Šivickis, 1934 (12) ; étude en cours (13). NB G. tigrinus et $P$. elegans ont été enregistrés dans la lagune de Curonian en 2004 (Daunys et Zettler, 2006 ; Zettler et Daunys, 2007).

\begin{tabular}{|l|c|c|c|c|}
\hline Oder/Family/Species & Appearance & Origin & Vectors & References \\
\hline $\begin{array}{l}\text { Leptolida, Olindiasidae } \\
\text { Craspedacusta sowerbii }\end{array}$ & $<2000(2002)$ & EA & A & 1 \\
\hline $\begin{array}{l}\text { Veneroida, Dreissenidae } \\
\text { Dreissena polymorpha }\end{array}$ & 1800 s (1934) & PC & IS, A, D, N, MS & 10,12 \\
\hline $\begin{array}{l}\text { Neotaenioglossa, Lithoglyphidae } \\
\text { Lithoglyphus naticoides }\end{array}$ & 1800 s (1930s) & PC & IS, N, A & 10,11 \\
\hline $\begin{array}{l}\text { Amphipoda, Corophiidae } \\
\text { Chelicorophium curvispinum }\end{array}$ & $<1900(1921)$ & PC & IS, N, MS & 6,8 \\
\hline $\begin{array}{l}\text { Gammaridae } \\
\text { Gammarus tigrinus } \\
\text { Chaetogammarus warpachowskyi }\end{array}$ & 2000 s (2008) & NA & MS & 13 \\
\hline $\begin{array}{l}\text { Pontogammaridae } \\
\text { Pontogammarus robustoides } \\
\text { Obesogammarus crassus }\end{array}$ & $1960(1961)$ & PC & D, N, U, MS & 4 \\
\hline $\begin{array}{l}\text { Mysida, Mysidae } \\
\text { Paramysis lacustris } \\
\text { Limnomysis benedeni } \\
\text { Hemimysis anomala }\end{array}$ & $1960(1961)$ & PC & D, N, U, MS & 4 \\
\hline $\begin{array}{l}\text { Decapoda, Astacidae } \\
\text { Astacus leptodactylus } \\
\text { Pacifastacus leniusculus }\end{array}$ & $1960(1961)$ & PC & D, N & 4 \\
\hline $\begin{array}{l}\text { Cambaridae } \\
\text { Orconectes limosus }\end{array}$ & $1960(1961)$ & PC & D, N, MS & 4 \\
\hline $\begin{array}{l}\text { Palaemonidae } \\
\text { Palaemon elegans }\end{array}$ & $1960(1967)$ & PC & D & 5 \\
\hline
\end{tabular}


populations and the presence of the zebra mussel in rivers is sustained by such dispersal. The presence of $D$. polymorpha in the mouth of the Šventoji River, which empties into the sea and has no source population upstream or hydrological link with other river basins, suggests invasion due to marine shipping (Figure 1C).

Other early invaders occur mainly in the Nemunas River. The snail $L$. naticoides also inhabits the large tributaries of the Nemunas River, and was observed in this study as well as previous surveys (Schlesch and Krausp, 1938; Pliūraitè, 2006). Natural dispersal seems to be responsible for upstream expansion of the species in the tributaries of the Nemunas River, whilst invasion into the Elektrènai WR most probably resulted from human-mediated accidental introduction (Figure 1D). The distribution of $C$. curvispinum in the Nemunas River basin is confined to the Nemunas River with no expansion upstream in its tributaries. Its presence in the mouth of the Šventoji River indicates that marine shipping may also facilitate the species expansion as natural dispersal of the species though coastal Baltic waters seems very unlikely (Figure 1E).

It is worth noting that the first invasion wave associated with the central European corridor also included the Ponto-Caspian gammarid Chaetogammarus ischnus Stebbing, 1906, which appeared in the Baltic Sea basin during the early 1900's (Jazdzewski, 1980), and was discovered in the lower section of the Nemunas River in 1960 (Gasiūnas, 1963). Recently, the species has not been encountered, and has most probably become extinct (Arbačiauskas, 2008).

The last early invader was the narrow-clawed crayfish $A$. leptodactylus which was deliberately introduced to Lithuanian waters in the second half of 19th century (Cukerzis, 1970). During the 1960s the species was present in around 30 lakes (Šestokas, 1969). Today, it has vanished from some of these lakes, but appears in a few others, probably due to unofficial introductions (Burba, 2008). This species did not exhibit a noticeable natural dispersal in Lithuanian waters however, its presence at a few localities may be attributed to migration through the rivers.

\section{> SECOND INVASION WAVE}

The second wave of NIMS is mainly represented by peracaridans which were deliberately transferred from the Ponto-Caspian region in an attempt to supplement the fish-food resources in inland waters. The amphipods $P$. robustoides, O. crassus and C. warpachowskyi, and mysids $P$. lacustris, $L$. benedeni and $H$. anomala were introduced into the Kaunas WR on the Nemunas River in 1960-1961 (Gasiūnas, 1972; Arbačiauskas, 2002). The current distribution of these peracaridan species across Lithuanian waters has resulted from natural dispersal, primarily downstream migration and secondary introductions. These species, excluding the mysid $H$. anomala, have colonised the Nemunas River below Kaunas WR and reached the Curonian Lagoon where they have established sustainable populations (Arbačiauskas, 2002). Although records do not show the permanent establishment of $H$. anomala in the Nemunas River downstream of the Kaunas WR and the Curonian Lagoon, genetic analysis has confirmed its invasion of the Baltic Sea from the Kaunas WR (Audzijonyte et al., 2008).

The distribution pattern of the pontogammarid $P$. robustoides in the Nemunas River suggests no upstream expansion from the Kaunas WR, but invasion of the middle section of the river by downstream dispersal from Lake Daugai (7, see Figure 1) where it was introduced in 1965 (Arbačiauskas et al., 2010). P. robustoides was observed in the stream flowing from Lake Daugai and further downstream, but for a long time was undetectable in the Merkys River which is characterised as a cold-water river. It was concluded that cold-water rivers were not a suitable environment for establishment of this pontogammarid (Arbačiauskas, 2005). However, annual investigations of the lowest stretch of the Merkys River have shown that it appeared in the macroinvertebrate assemblage during and since 2007, and a few individuals of this species were detected in the Nemunas River at the mouth of the Merkys River in 2008. A distance of $70 \mathrm{~km}$ from Lake Daugai had been crossed in about 40 years which suggests expansion at a rate of about $2 \mathrm{~km}$ per year (Figures $1 \mathrm{~A}, 1 \mathrm{~F}$ ). This estimate should be treated as an assessment for a hostile environment, i.e. small or medium-sized cold-water rivers, as for large rivers 
estimated rates of NIMS downstream dispersal are much higher (Leuven et al., 2009). Most importantly however, is that $P$. robustoides exhibited the ability to establish a viable population in cold waters, a rather unexpected finding based on previous knowledge.

In some tributaries of the Nemunas River, such as the Šešupe and Minija rivers, $P$. robustoides was detected quite far upstream and its ability to spread upstream under suitable environmental conditions should be not ruled out. Together with the gammarid $C$. warpachowskyi, the Ponto-Caspian amphipods penetrated from Lake Žeimenys (20) through a narrow canal with strong flow velocity upstream to Lake Lūšiai (12) where they are currently well-established (Table I; Figures 1F, 1H). In stagnant waters, the Ponto-Caspian amphipods $P$. robustoides, $O$. crassus and $C$. warpachowskyi currently occur mostly in those lakes and water reservoirs where they were deliberately introduced, although they are found in a few other localities due to unofficial introductions (Table I). The presence of $P$. robustoides and $C$. warpachowskyi in the mouth of the Šventoji River indicates that their local spread may have been facilitated by marine shipping or that they may be capable of migration through coastal Baltic waters.

When comparing the dispersal abilities of mysids $L$. benedeni and $P$. lacustris, the latter species showed substantially higher potential for natural spread in freshwater environments. $P$. lacustris colonised the Nemunas River upstream from the Kaunas WR, invaded upstream from Žeimenys (20) to Lūšiai (12) lake, recently dispersed from Lake Rūžas (16) through lake Apvardai (4) to the largest Lithuanian lake, Lake Drūkšiai (11), where it was recorded as established in 2006, and was able to pass downstream through an electric power plant located on the Dysna River which flows from Lake Dysnai (9). The presence of both species in the mouth of the Šventoji River confirms the ability of both species to spread over Baltic coastal water with human aid or naturally (Figure $1 \mathrm{H}$ ).

The last species attributed to the second invasion wave was the signal crayfish $P$. leniusculus. This non-indigenous crayfish species was introduced to a few isolated lakes in 1972 (Cukerzis, 1979). Its further spread to a few lakes resulted from intentional but illegal introductions. Invasion of the Žeimena River, where the species was observed as established in 2007 (Rakauskas et al., 2010), was due to escape from the Žeimena Fish Hatchery. P. leniusculus was also found in the flowing waters of the Mera River (tributary of the Žeimena River), the result of an illegal introduction (Figure 2C).

\section{> THIRD INVASION WAVE}

The most prominent NIMS of the third invasion wave was the spiny-cheek crayfish O. limosus. It has invaded by natural dispersal from Polish waters during the early 1990s, and was first recorded far away from the Polish border in a closed lake in 1994, where it was, most probably, introduced by humans (Koreiva, 1994; Tougbol et al., 1998). The main pathway for its invasion of Lithuanian waters remains undetermined. Expansion of $O$. limosus may have proceeded through tributaries of the Nemunas River as well as the Augustow Canal, which connects basins of the Vistula and Nemunas Rivers in Belarus. However, it was due to natural dispersal that the spiny-cheek crayfish colonised the entire Nemunas River. The river survey (2007-2008) suggests that the waterway connecting the Nemunas and Lielupe (Latvia) rivers (the Nevėžis River, Sanžilè Canal, and Lèvuo and Mūša rivers) was most probably the route for the natural dispersal of $O$. limosus to Latvian waters, where it was first recorded in the Lielupe River in 2007 (N. Grudule, pers. communication) (Figures 2A, 2D). The spiny-cheek crayfish reached the mouth of the Nevezžis River in approximately 1996 and a distance of $270 \mathrm{~km}$ between the river mouth and the site of its record in the Lielupe River in Latvia was covered in ten years, suggesting expansion at a rate of about $30 \mathrm{~km}$ per year. The species also showed an ability to invade the lower reaches of the cold-water Merkys River. However, invasions of other rivers, e.g. the Venta, Neris and Šventoji rivers seem to be a result of human-mediated introductions. The presence of the spiny-cheek crayfish in the Venta River resulted from illegal introduction. It was recorded at two sites but was absent downstream as well as upstream including the Venta-Dubysa Canal which connects the basins of the Nemunas and Venta rivers. In the Neris River, the species was observed only in the territory of Vilnius City. Whilst the Šventoji River has no connection with other river basins, it flows into the sea and the possibility 
of migration through coastal waters should not be excluded as the species has been observed in these waters. Due to unofficial introductions $O$. limosus now inhabits a considerable number of lakes of various size and it's expansion is rapidly ongoing (Figures 2A, 2D).

Two other recent NIMS, the American gammarid G. tigrinus and the marine shrimp $P$. elegans were recorded in the mouth of the Šventoji River, which they have reached with the aid of shipping and by the natural spread over coastal waters, respectively. It is noteworthy, that the large-scale dispersal of $P$. elegans is also considered to be related to shipping (Kohn and Gosselck, 1989). Both these species have been reported as recent inhabitants of the Curonian Lagoon (Zettler and Daunys, 2007).

The last species attributed to the third invasion wave was the freshwater jellyfish $C$. sowerbii. The specific time period and vector responsible for its invasion remain uncertain, however, human-mediated incursion seems most likely. It was detected during an exceptionally warm summer when favourable conditions for mass medusae production were present (Arbačiauskas and Lesutienè, 2005).

\section{NIMS CHARACTERISTIC}

To date, 15 NIMS have been recorded in Lithuanian fresh waters and the majority of these $(60 \%)$ are of Ponto-Caspian origin (Table II). Crustaceans dominate comprising $80 \%$ of observed invasive species. With respect to feeding habit, collector-gatherers are the most numerous ( $>70 \%$ of the total) (Figure 3). All these eleven collector-gatherer (peracaridan and decapod) species are also capable of predatory feeding, consequently, they can be characterized as omnivores. Among them, only the mysid $L$. bendeni was considered to rely on vegetal food and detritus (Gergs et al., 2008), however, recently has been reported for feeding on zooplankton (Fink et al., 2011). Analysis of all NIMS occurring in Lithuanian inland waters (including 10 species recorded only in the Curonian Lagoon, see the Baltic Sea Alien Species database, http://www.corpi.ku.It/nemo/) results in the same patterns in taxonomy and feeding habit (Figure 3). The observed domination by NIMS collector-gatherers conflicts with Karatayev et al. (2009) who concluded that suspension feeders were the most abundant group among successful invaders. The difference is probably attributed to the substantial number of deliberate introductions to Lithuanian waters. The primary invasion of eight crustacean species (six peracaridans and two crayfish), comprising 53\% of NIMS recorded in fresh waters (32\% when including the Curonian Lagoon), resulted from their translocation for fishery and aquaculture enhancement. Despite the effect that deliberate introductions may have had on feeding habits, the ability of an invader to utilize a wide spectrum of resources, including animal food, should be considered and is almost certainly related to species success in a novel environment. Therefore, collector-gatherers capable of animal food consumption may be more successful than suspension feeders. The importance of predatory feeding for invasive success has been revealed for freshwater fish (Moyle and Light, 1996). A propensity for predation may determine the extent of a newcomer's impact on resident communities and this aspect warrants a special analysis.

\section{FUTURE DISPERSAL AND INVASIONS}

Further dispersal and increased distribution of the early invaders of Lithuanian inland waters within the country are likely to be limited in the future. Records of new localities would supplement information on their current distribution. Collected data suggests that the amphipod C. curvispinum inhabits the Nemunas River, while the snail L. naticoides occurs additionally in the lower sections of large Nemunas tributaries. Discovery of new populations of the snail in stagnant waters however, seem very likely. It was estimated that about $17 \%$ of Belarusian lakes with a surface area greater than 10 ha contain the zebra mussel D. polymorpha (Karatayev et al., 2003). Although unrecorded, the distribution of the zebra 


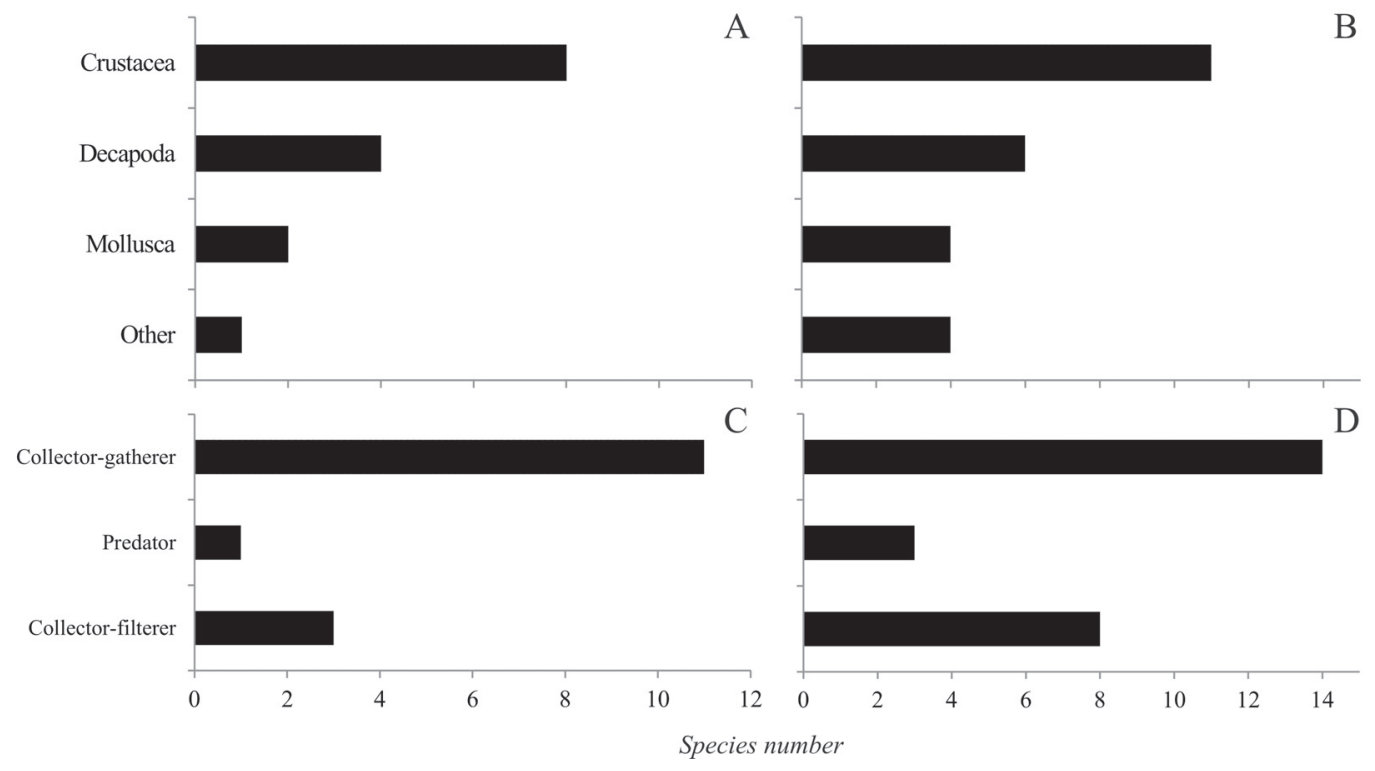

\section{Figure 3}

Taxonomic $(A, B)$ and feeding mode $(C, D)$ compositions of non-indigenous macroinvertebrate species inhabiting Lithuanian fresh waters $(A, C)$ and those including the species recorded in the Curonian Lagoon (B, D) (in total 25 species, http://www.corpi.ku.lt/nemo/). For taxonomic composition, crustaceans (excluding decapods), decapods and molluscs are indicated separately, and "other" includes Cnidaria, Annelida and Nematoda. Feeding groups based on Mandaville (2002). Predator group in (D) includes one parasite species.

\section{Figure 3}

Compositions taxonomiques $(A, B)$ et mode d'alimentation $(C, D)$ des espèces non-indigènes de macroinvertébrés vivant dans les eaux douces lituaniennes $(A, C)$ et des espèces rencontrées dans la lagune Curonian (B, D) (au total 25 espèces, http://www.corpi.ku.lt/nemo/). Pour la composition taxonomique, les crustacés (hors décapodes), les décapodes et mollusques sont indiqués séparément, et les « autres » comprend Cnidaires, Annélides et Nématodes. Les groupes trophiques sont basés sur Mandaville (2002). Le groupe prédateur (D) comprend une espèce de parasite.

mussel across Lithuanian lakes must be wider, as deliberate translocations were involved and the species may occur in 200 or more lakes. The narrow-clawed crayfish A. leptodactylus inhabits a limited number of lakes mainly in the north-eastern part of the country. Its distribution is unlikely to increase in the future and may even decrease due to the expansion of other non-indigenous crayfish species.

Among deliberately introduced Ponto-Caspian peracaridan species, the mysid $P$. lacustris and pontogammarid $P$. robustoides are the best adapted to freshwater environments. Their current distribution is the widest and they may be present in a few additional localities (Figures 1F, 1K). These species were deliberately introduced into most of the inhabited stagnant water bodies and additional localities would have resulted from unofficial introductions or natural dispersal (Table I). Not all lakes which had been subject to deliberate introductions have been checked for species establishment. Therefore, a discriminant analysis on lake morphometric characteristics was performed to predict lakes which may contain $P$. robustoides and $P$. lacustris. For both species the most important variable for discrimination between suitable and non-suitable lakes was the surface area. The classification functions predicted that the pontogammarid and mysid may additionally inhabit one and two uninvestigated lakes, respectively (Table III). Due to the ecological plasticity of $P$. robustoides, which exhibits the ability to establish in cold-water rivers and may tolerate quite a low water mineralisation (Arbačiauskas, 2005), and the high dispersal potential of $P$. lacustris, distributions of these species in the Lithuanian fresh waters are likely to increase. However, their expansion across stagnant waters 


\section{Table III}

Results of stepwise discriminant analysis on lake log-transformed morphometric characteristics for establishment of Pontogammarus robustoides (PR) and Paramysis lacustris (PL) after introduction. Variables included into models: surface area (S), average depth $\left(\mathrm{H}_{2}\right)$ and annual water circulation (AC). Classification functions obtained for suitable and non-suitable lakes for $P R$ and PL were: model Wilks' Lambda $=0.701, \mathrm{~F}_{2.39}=8.33, \mathrm{P}<0.001$, functions $-22.07+4.75 \mathrm{~S}+$ $4.55 \mathrm{H}_{a}$ and $-12.76+3.72 \mathrm{~S}+3.39 \mathrm{H}_{\mathrm{a}}$; model Wilks' Lambda $=0.528, \mathrm{~F}_{2.29}=12.96, \mathrm{P}<0.001$, functions $-32.07+6.65 \mathrm{~S}+4.02 \mathrm{AC}$ and $-19.42+4.93 \mathrm{~S}+3.46 \mathrm{AC}$, correspondingly.

Tableau III

Les résultats de l'analyse discriminante pas à pas sur les caractéristiques morphométriques logtransformées des lacs pour l'implantation de Pontogammarus robustoides (PR) et Paramysis lacustris $(\mathrm{PL})$ après leur introduction. Les variables incluses dans les modèles : la surface $(S)$, la profondeur moyenne $\left(H_{\mathrm{a}}\right)$ et la circulation d'eau annuelle $(A C)$. Les fonctions de classification obtenues pour les lacs propices ou non pour PR et PL ont été : modèle de Wilks Lambda $=0,701, F_{2,39}=8,33, P<0,001$, fonctions $-22,07+4,75 \mathrm{~S}+4,55 \mathrm{H}_{\mathrm{a}}$ et $-12,76+3,72 \mathrm{~S}+3,39 \mathrm{H}_{\mathrm{a}}$; modèle de Wilks Lambda $=0,528, F_{2,29}=$ 12,96, $\mathrm{P}<0,001$, fonctions $-32,07+6,65 S+4,02 \mathrm{AC}$ et $-19,42+4,93 S+3,46 \mathrm{AC}$, respectivement.

\begin{tabular}{|l|c|c|c|c|c|}
\hline Species & Variable & Wilks' Lambda & $\mathrm{df}$ & $F$ & $P$ \\
\hline PR & $S$ & 0.863 & 1,39 & 9.05 & 0.004 \\
& $H_{\mathrm{a}}$ & 0.744 & 1,39 & 2.42 & 0.13 \\
\hline PL & $S$ & 0.958 & 1,29 & 25.10 & $<0.001$ \\
& $A C$ & 0.568 & 1,29 & 2.17 & 0.15 \\
\hline
\end{tabular}

may be limited, as both species are generally only capable of long-term survival in large lakes. Distributions of the other introduced Ponto-Caspian peracaridans (L. benedeni, $H$. anomala, $O$. crassus and $C$. warpachowskyi in particular) in fresh waters may be predicted to remain stable in the future.

The pontogammarid $P$. robustoides has substantially increased its range in the Baltic Sea basin beyond Lithuanian waters and has already invaded the North Sea basin (Arbačiauskas and Gumuliauskaite, 2007). The mysid $P$. lacustris however, is found in only a few localities in Latvia and Estonia where it was deliberately introduced (Arbačiauskas et al., 2010) and was recently recorded in the Nemunas River in Belarus, in the vicinity of the Lithuanian border (Semenchenko et al., 2009). Due to the dispersal ability exhibited in Lithuanian waters, its distribution in the Baltic Sea basin should be wider and its further expansion through the Central invasion corridor or Baltic coastal waters can definitely be expected. It should be noted that the species is currently overlooked as it requires special sampling and is usually absent from the dip net samples routinely used for macroinvertebrate research.

The amphipod G. tigrinus currently occurs in the mouth of the Šventoji River and the northern part of the Curonian Lagoon (Daunys and Zettler, 2006), however, we predict that it will not manage to penetrate and establish in the Nemunas River. The lower section of this river and the freshwater middle part of the Curonian Lagoon are occupied by $P$. robustoides which being abundant and larger in body size, thus competitively superior, could prevent the establishment of $G$. tigrinus. The detrimental impact of the pontogammarid on native peracaridan species and resident macroinvertebrate communities has been confirmed (Arbačiauskas and Gumuliauskaitè, 2007; Gumuliauskaitè and Arbačiauskas, 2008).

The distribution of the jellyfish $C$. sowerbii in Lithuanian fresh waters may be wider than recently documented and warrants further observation. The shrimp $P$. elegans, a brackish water species, may only occur in fresh waters in close vicinity to the Baltic coast. Whilst the range expansion of the latest crayfish invaders, the signal crayfish $P$. leniusculus and especially the spiny-cheek crayfish $O$. limosus seems very probable. The main vectors of their expansion will remain the same, illegal introductions as well as natural dispersal through flowing waters. 
The current NIMS distributions and future structure of freshwater macroinvertebrate assemblages may be altered, perhaps drastically by new invaders and especially by highimpact invaders (Dick and Platvoet, 2000). The main pathways of new invasions may be the Central invasion corridor, particularly if the hydrological connection between the Pripyat and Nemunas rivers is re-established, and the Baltic coastal waters. The most probable new invasive species of Lithuanian fresh waters are listed in Table IV. Some of them, for example the North American snail Physella acuta, which was detected in the Belarusian part of the Nemunas River (Semenchenko et al., 2009) or New Zealand snail Potamopyrgus antipodarum which in addition to neighbouring countries also occurs in the Curonian Lagoon (Zettler and Daunys, 2007), may already be present, albeit not yet recorded. Generally, it can be predicted that the ongoing worldwide development of the market economy and international trade will increase the diversity of donor areas, pathways and invasion vectors, such as recreational activity, ornamental and live food trade, etc. Consequently, the rate of new introduction of non-indigenous species will substantially increase and some of newcomers may encounter a suitable environment for establishment.

\section{CONCLUDING REMARKS}

The first non-indigenous aquatic species appeared in Lithuanian fresh waters at the end of the 18th century after connection of the river basins feeding the Baltic and Black seas by canals. To date, fifteen NIMS have been recorded. Deliberate introduction of peracaridans and crayfish for fishery and aquaculture enhancement has substantially contributed to the current composition of Lithuanian NIMS. Amongst them, the invaders of Ponto-Caspian origin

\section{Table IV}

Most probable Lithuanian fresh water invaders recorded in the Pripyat and Nemunas rivers in Belarus (Semenchenko et al., 2009) and Polish inland waters (Alien Species in Poland database, http://www.iop.krakow.pl/ias/).

\section{Tableau IV}

Espèces envahissantes lituaniennes d'eau douce signalées dans les rivières Pripyat et Nemunas en Biélorussie (Semenchenko et al., 2009) et les eaux intérieures polonaises (espèces exotiques en Pologne base de données, http://www.iop.krakow.pl/ias/)

\begin{tabular}{|c|c|c|}
\hline Phylum(Subphylum)/Species & Origin & $\begin{array}{l}\text { Probable donor } \\
\text { country }\end{array}$ \\
\hline \multicolumn{3}{|l|}{ Annelida } \\
\hline Caspiobdella fadejewi Selensky,1915 & Ponto-Caspian & Belarus \\
\hline Hypania invalida Grube, 1860 & Ponto-Caspian & Belarus \\
\hline \multicolumn{3}{|l|}{ Crustacea } \\
\hline Dikerogammarus haemobaphes Eichwald, 1841 & Ponto-Caspian & Poland or Belarus \\
\hline Dikerogammarus villosus Sowinski, 1894 & Ponto-Caspian & Poland or Belarus \\
\hline Obesogammarus obesus Sars, 1894 & Ponto-Caspian & Belarus \\
\hline \multicolumn{3}{|l|}{ Mollusca } \\
\hline Ferrisia fragilis Tryon, 1863 & North American & Belarus \\
\hline Physella acuta Draparnaud, 1805 & North American & Belarus or Poland \\
\hline Physella integra Haldeman, 1841 & North American & Belarus \\
\hline Potamopyrgus antipodarum Gray, 1853 & New Zealand & Poland or Belarus \\
\hline
\end{tabular}


dominate, the most numerous are crustaceans, whilst the collector-gatherers are the largest group with respect to feeding mode. The most important primary invasion vectors inferred in the present study were inland shipping and deliberate introductions, whilst secondary spread proceeded by means of various human mediated vectors and naturally.

Collected data suggest that current distribution of the majority of NIMS in Lithuanian fresh waters may remain stable, although the further expansion of a few species, the PontoCaspian peracaridans $P$. robustoides and $P$. lacustris, and crayfish $P$. leniusculus and O. limosus in particular, which have good dispersal abilities and are well-adapted to freshwater environments, seems very probable. Invasions of new non-indigenous species and diversification of donor areas, dispersal pathways and vectors due to the growth of an international trade are also expected. New invaders of Lithuanian fresh waters may alter the current distribution of resident NIMS and could have multiple effects on the ecosystems they invade.

\section{ACKNOWLEDGEMENTS}

The study was supported by the Research Council of Lithuania, Project No. LEK-18/2010. We are grateful to Rachel Benstead for substantial linguistic improvement of the manuscript. It also benefited from referees' comments.

\section{REFERENCES}

Arbačiauskas K., 2002. Ponto-Caspian amphipods and mysids in the inland waters of Lithuania: history of introduction, current distribution and relations with native malacostracans. In: Leppakoski E., Gollasch S. and Olenin S. (eds.), Invasive Aquatic Species of Europe, Distribution, impacts and management, Kluwer Academic Publishers, Dordrecht, Boston, London, 384-398.

Arbačiauskas K., 2005. The distribution and local dispersal of Ponto-Caspian Peracarida in Lithuanian fresh waters with notes on Pontogammarus robustoides population establishment, abundance, and impact. Oceanol. Hydrobiol. Stud., 34, Suppl. 1, 93-113.

Arbačiauskas K., 2008. Amphipods of the Nemunas River and the Curonian Lagoon, the Baltic Sea basin: where and which native freshwater amphipods persist? Acta Zool. Litu., 18, 10-16.

Arbačiauskas K. and Gumuliauskaitè S., 2007. Invasion of the Baltic Sea basin by the Ponto-Caspian amphipod Pontogammarus robustoides and its ecological impact. In: Gherardi F. (ed.), Biological Invaders in inland waters: profiles, distribution and threats, Springer, Dordrecht, The Netherlands, 463-477.

Arbačiauskas K. and Lesutienè J., 2005. The freshwater jellyfish Craspedacusta sowerbii in Lithuanian waters. Acta. Zool. Litu., 15, 60-63.

Arbačiauskas K., Rakauskas V. and Virbickas T., 2010. Initial and long-term consequences of attempts to improve fish-food resources in Lithuanian waters by introducing alien peracaridan species: a retrospective overview. J. Appl. Ichthyol., 26, Suppl. 2, 28-37.

Audzijonyte A., Wittmann, K.J. and Väinölä R., 2008. Tracing recent invasions of the Ponto-Caspian mysid shrimp Hemimysis anomala across Europe and to North America with mitochondrial DNA. Divers. Distrib., 14, 179-186.

Bij de Vaate A., Jazdzewski K., Ketelaars H.A.M., Gollasch S. and Van der Velde G., 2002. Geographical patterns in range extension of Ponto-Caspian macroinvertebrate species in Europe. Can. J. Fish. Aquat. Sci., 59, 1159-1174.

Burba A., 2008. Assessment of crayfish situation in Lithuania and prognosis for the future. Žuvininkystė Lietuvoje, 8, 218-230 (in Lithuanian).

Cukerzis J., 1970. The biology of crayfish (Astacus astacus L.), Mintis, Vilnius, 206 p. (in Russian).

Cukerzis J., 1979. On acclimatization of Pacifastacus leniusculus Dana in an isolated lake. Freshwater Crayfish, 4, 445-450.

Daunys D. and Zettler M.L., 2006. Invasion of the North American amphipod (Gammarus tigrinus Sexton, 1939) into the Curonian Lagoon, south-eastern Baltic Sea. Acta Zool. Litu., 16, $20-26$.

Dick J.T.A. and Platvoet D., 2000. Invading predatory crustacean Dikerogammarus villosus eliminates both native and exotic species. Proc. R. Soc. B, 267, 977-983.

Dudgeon D., Arthington A.H., Gessner M.O., Kawabata Z.I., Knowler D.J., Leveque C., Naiman R.J., Prieur-Richard A.H., Soto D., Stiasny M.L.J. and Sullivan C.A., 2006. Freshwater biodiversity: importance, threats, status and conservation challenges. Biol. Rev., 81, 163-182. 
Fink P., Kottsieper A., Heynen M. and Borcherding J., 2011. Selective zooplanktivory of an invasive Ponto-Caspian mysid and possible consequences for the zooplankton community structure of invaded habitats. Aquat. Sci., DOI: 10.1007/s00027-011-0210-y.

Gailiušis B., Jablonskis J. and Kovalenkovienè M., 2001. Lithuanian rivers: hydrography and runoff, Lithuanian Energy Institute, Kaunas, 796 p. (in Lithuanian).

Gasiūnas I., 1963. The acclimatization of fodder crustaceans (of the Caspian relict type) into the reservoir of Kaunas Hydroelectric power station and the possibility of their transference into other water bodies. LTSR MA Darbai, Serija C 1, 30, 79-85 (in Russian).

Gasiūnas I., 1968. A mysid's Hemimysis anomala Sars acclimatization in the water reservoir of the Kaunas HEPS. LTSR MA Darbai, Serija C, 47, 71-73 (in Russian).

Gasiūnas I., 1972. Enrichment of fodder basis of water bodies of Lithuania by acclimatized crustaceanslike organisms from the Caspian Sea complex. In: Maniukas J. and Virbickas J. (eds.), On the breeding of fish and crustacean-like organisms in the water bodies of Lithuania, Mintis, Vilnius, 57-68 (in Russian).

Genovese P., 2007. Towards a European strategy to halt biological invasions in inland waters. In: Gheraradi F. (ed.), Biological Invaders in inland waters: profiles, distribution and threats, Springer, Dordrecht, The Netherlands, 627-637.

Gergs R., Hanselmann A.J., Eisele I. and Rothhaupt K.O., 2008. Autecology of Limnomysis benedeni Czerniavsky, 1882 (Crustacea: Mysida) in Lake Constance, southwestern Germany. Limnologica, 38, 139-146.

Gumuliauskaitè S. and Arbačiauskas K., 2008. The impact of the invasive Ponto-Caspian amphipod Pontogammarus robustoides on littoral communities in Lithuanian lakes. Hydrobiologia, 599, 127-134.

Jazdzewski K., 1980. Range extensions of some gammaridean species in European inland waters caused by human activity. Crustaceana, Suppl. 6, 84-107.

Jazdzewski K. and Konopacka A., 2000. Immigration history and present distribution of alien crustaceans in Polish waters. Crustacean Issues, 12, 55-64.

Jazdzewski K., Konopacka A. and Grabowski M., 2004. Recent drastic changes in the gammarid fauna (Crustacea, Amphipoda) of the Vistula River deltaic system in Poland caused by alien invaders. Divers. Distrib., 10, 81-87.

Karatayev A.Y., Burlakova L.E., Padilla D.K. and Johnson L.E., 2003. Patterns of spread of the zebra mussel (Dreissena polymorpha (Pallas)): the continuing invasion of Belarusian lakes. Biol. Invasions, 5, 213-221.

Karatayev A.Y., Mastitsky S.E., Burlakova L.E. and Olenin S., 2008. Past, current, and future of the central European corridor for aquatic invasions in Belarus. Biol. Invasions, 10, 215-232.

Karatayev A.Y., Burlakova L.E., Padilla D.K., Mastitsky S.E. and Olenin S., 2009. Invaders are not a random selection of species. Biol. Invasions, 11, 2009-2019.

Kohn J. and Gosselck F., 1989. Identification Key for the Malacostraca of the Baltic Sea. Mitt. Zool. Mus. Berl., 65, 3-114.

Koreiva Č., 1994. Orconectes limosus in Lithuania. Crayfish news: IAA Newsletter, $16,7$.

Lepehne O., 1924. Corophium curvispinum in Ostpreussen. Schriften der Physikalisch-Ökonomischen Gesellschaft zu Königsberg, 64, 61.

Leuven R.S.E.W., van der Velde G., Baijens I., Snijders J., van der Zwart C., Lenders H.J.R. and Bij de Vaate A., 2009. The river Rhine: a global highway for dispersal of aquatic invasive species. Biol. Invasions, 11, 1989-2008.

Lonsdale M., 1999. Global patterns of plant invasions and the concept of invasibility. Ecology, 80 , 1522-1536.

Mandaville S.M., 2002. Benthic macroinvertebrates in freshwaters - taxa tolerance values, metrics, and protocols, Project H-1, Soil \& Water Conservation Society of Metro Halifax, $128 \mathrm{p}$.

Mikha O., 1901. Review and statistics of crayfish export from Russia. Vestnik Rybopromyshlennosti, 11, 598-613 (in Russian).

Millennium Ecosystem Assessment, 2005. Ecosystem and human well-being: biodiversity synthesis, World Resources Institute, Washington, DC, $86 \mathrm{p}$.

Moyle P.B. and Light T., 1996. Biological invasions of fresh water: empirical rules and assembly theory. Biol. Conserv., 78, 149-161.

Pliūraitè V., 2006. Patterns of macrozoobenthos changes in Lithuanian rivers, Ph.D. thesis, Vilnius University, 176 p. (in Lithuanian).

Rabitsch W. and Essl F., 2006. Biological invasions in Austria: patterns and case studies. Biol Invasions, 8, 295-308.

Rakauskas V., Ruginis T. and Arbačiauskas K., 2010. Expansion of the spinycheek crayfish, Orconectes limosus Rafinesque, 1817, in the Nemunas River Basin, Lithuania. Freshwater Crayfish, 17, 73-76.

Ricciardi A. and Rasmussen J.B., 1998. Predicting the identity and impact of future biological invaders: a priority for aquatic resource management. Can. J. Fish. Aquat. Sci., 55, 1759-1765.

Schlesch H., 1937. Bemerkungen über die Verbreitung der Süsswasser- und Meeresmollusken im östlichen Ostseegebiete. Tartu Ülikooli juures oleva Loodusuurijate Seltsi Aruanded, 43, 37-64. 
Schlesch H. and Krausp C., 1938. Zur Kenntniss der Land- und Süsswassermollusken Litauens. Archiv für Molluskenkunde, 70, 73-125.

Semenchenko V.P., Rizevsky V.K., Mastitsky S.E., Vezhnovets V.V., Pluta M.V., Razlutsky V.I. and Laenko T., 2009. Checklist of aquatic alien species established in large river basins of Belarus. Aquat. Invas., 4, 337-347.

Šestokas J., 1969. Crayfish distribution, stock status and it's restoration potential in Lithuania, Ph.D. thesis, Institute of Zoology and Parasitology, Academy of Sciences of Lithuanian SSR, 281 p. (in Lithuanian).

Shea K. and Chesson P., 2002. Community ecology theory as a framework for biological invasions. Trends Ecol. Evol., 17, 170-176.

Šivickis P., 1934. Investigations of fauna of Šventoji harbour in summer. Kosmos, 15, 379-398 (in Lithuanian).

Tougbol T., Skurdal J. and Burba A., 1998. Freshwater crayfish in Lithuania, I. Action plan for crayfish management, II. Crayfish status report, Report No. 12, Eastern Norway Research Institute, Lillehammer, $83 \mathrm{p}$.

Zettler M.L. and Daunys D., 2007. Long-term macrozoobenthos changes in a shallow boreal lagoon: Comparison of a recent biodiversity inventory with historical data. Limnologica, 37, 170-185. 